\title{
A Comparative Study of the Concept of Time: Status and Age in the Stories of Katherine Mansfield
}

\author{
Maryam Jafari ${ }^{1, ~ *}$, Fatemeh Sadat Basirizadeh ${ }^{2}$ \\ ${ }^{1}$ Department of English Literature, Science and Research Branch University, Tehran, Iran \\ ${ }^{2}$ Young Researchers and Elite Club, Science and Research Branch, Islamic Azad University, Tehran, Iran
}

Email address:

Maryam.jafari@yahoo.com(M. Jafari)

${ }^{*}$ Corresponding author

\section{To cite this article:}

Maryam Jafari, Fatemeh Sadat Basirizadeh. A Comparative Study of the Concept of Time: Status and Age in the Stories of Katherine Mansfield. International Journal of Philosophy. Vol. 6, No. 1, 2018, pp. 8-18. doi: 10.11648/j.ijp.20180601.12

Received: February 11, 2018; Accepted: March 27, 2018; Published: May 8, 2018

\begin{abstract}
Modernism brought with itself a great change to the philosophical and scientific ideas. Philosophies about time were not free from this change and the French philosopher Henri Bergson reinterpreted time. He divided time into specialized (linear time) and duration. The artist and the writers of the modern era were much influenced by these ideas and Katherine Mansfield was among this group. She made use of new techniques and methods in order to write her short stories. One of the important characteristic of her stories is the shift in time that she uses, and plunging into the consciousness of her characters in order to show their inner time and world. Her characters are either rooted in their past and totally forget about linear time, or they are slaves of the linear time allowing it to influence their life. Her stories show that some people fit very well with the clock and some do not. Her characters perceive time differently according to the age and social conditions that they are living in. The aim of this study is to explore how Mansfield deals with time in her stories and what methods she uses to demonstrate time in them from Bergson's point of view. It will also investigate the significance of time for her characters and will show whether they can fit with the clock or not. Finally, it will analyze how being in a certain age and class will affect the way people perceive time.
\end{abstract}

Keywords: Bergson, Short Story, Modernism, Time, Linear Time, Duration

\section{Introduction}

At the beginning of the twentieth century the perception of time had changed as a result of technological innovations like the telephone or the wireless telegraph and this had caused communication to become more easily. At the same time scientific developments displayed the way time was experienced and conceptualized. In philosophy Henry Bergson (1859-1941) said that we have to kinds of time, the mechanical and the psychological and made a distinction between these two. This philosophical idea had a great influence on the writers of the age such as Katherine Mansfield (1888-1923. Katherine Mansfield was one of the most influential writers of the twentieth century; she is always praised for her unique style of writing. Her stories usually dramatize webs of personal thoughts and interrelationships and set them in descriptive, suggestive, and even symbolic details. She often leads the reader to moments of revelation, or "epiphanies". Due to her ill health and fear of death, the moment of being was very important to her and she showed it in her stories as much as she could. Her themes are usually joy in beauty, yearnings for happiness (particularly by women), disappointment, callousness, and cruelty.

As a person who was living at the beginning of the twentieth century one of the most important issues in her writing is the concept of time. She pays a lot of attention to it and she creates a new approach towards it in her stories. She said in her journal that the sudden moment of revelation in her stories represents a suspension of time and she uses ellipses in most of her stories to show it. Her characters are usually either under the influence of linear time, and affected by it, or they are lost in their own world of duration. Katherine Mansfield's concept of time influenced both characterization and structure in her stories. Therefore, the 
aim of this research is to analyze the effects of time on Mansfield's characters and structure of her stories according to Bergson's theory of time. Bergson believes that there are two types of time, the linear time and the inner time (duration), but he asserts that reality is only in duration and freedom can be only achieved through duration. He also believes that linear time imposes a false sense of order on human behavior and memory brings the past to the present. Therefore those under the burden of linear time are in kind of a prison. This paper is going to analyze Katherine Mansfield's treatment of time and see how she was influenced by Bergson's philosophy of time and what impact it had on her writing. During Modernism time became an important aspect for different writers and artists. They tried to make use of different techniques and methods in their stories in order to show time. Katherine Mansfield was one of these writers that made use of different techniques in her stories in order to show time. She was much influenced by the French philosopher Henri Bergson and made use of his thoughts in her stories. This paper is going to present how Mansfield shows the concept of time in her stories and what strategies she uses to show the inner time and outer time of her characters. The study also wants to show effects of time on her characters and how being in a certain age of life, status and class in society affects the perceiving of time in people. These objectives will be analyzed through there of her stories, which are in the following order: "Mille" "New Dresses".

One of the most important issues for Mansfield in her stories is the notion of time. She usually tends to show time in her stories by her characters inner times and experiences. If there is any time in her stories there are many shifts in them, plunging from one characters mind to the other. It seems that she was influences by Bergson's concept of time in writing her stories. While working as an editor for John Middleton Murray in his journal called the Rhythm she was introduced to Bergson's theories for the first time. The way she shows her characters inner time in her stories, there duration and intuition seems close to Bergson's theory of duration which I will explain. As this paper shows, "time" became an important issue during Modernism. The nature of time was questioned and finally redefined by Bergson. One important aspect of this reinterpretation of time was the separation between "time in the mind" and "time on the clock." Mansfield focused on "time in the mind," as the structure of her stories make clear. Likewise, Bergson introduced a dualist principle in his philosophy which separated the world of "real time" (duration) from the world of "specialized" time or "time on the clock." Bergson described the nature of "time in the mind" as flowing and heterogeneous and reversible since the past influenced the present, just as much as the present influenced the past. The re-conceptualization of time, however, went beyond a distinction between public and private time. Bergson differentiated between two kinds of memory: voluntary and involuntary memory, and developed an evolutionary theory that claimed the existence of a vital impulse (élan vital) which could only be grasped through intuition. In her stories Mansfield made a distinction between specialized time and duration. In "Millie" the specialized time is shown through the mention of the "clock" and the duration is revealed thorough the long sentences used in the story. Mansfield showed the continuity of duration in her stories by the special grammar and sentence structures that she used. She made use of present participles, metaphors and rhythmic sentences in order to show the continuity of duration.

\section{Methodology}

Just like the other writers and artists of the twentieth century Katherine Mansfield was influenced by the new philosophical and scientific innovations about time and tried to show them in her writings by adopting a new approach towards time. This research is going to analyze Katherine Mansfield's attitude towards time and the methods she used in her writings in order to show psychological time of her characters. Also it will investigate whether she was influenced by Bergeson's philosophy of time or not and if she was how she used his philosophy in her stories. In the study three of her short stories will be analyzed in order to show the important role which time plays in these stories and their protagonists. A close reading of these short stories will be done in order to explore the traces of linear and inner time in them, and see the effects of time on the characters life and how they look upon time in their life. The approach that will be used in order to achieve these goals is the philosophical approach of Bergson's theory of time. His focus is mainly on how Mansfield could have been introduced to Bergson's philosophy. With investigation of time on her stories he believes that Mansfield used inner time in her stories. In his essay Time and Freewill (1957) Bergson defines duration as something that its parts cannot be juxtaposed as a succession of distinct parts, with one causing the other. It is a pure mobility, constantly moving. No moment is ever recoverable; no moment is ever perceived as external to the living of it until after it has been experienced.

As Gillies asserts, "Bergson's view of time removes the external standard and replaces it with what the internal sense of time reveals-that real time is that in which people live and it is qualitative, not quantitative in nature"(102). He believes that, duration can only be approached through inner states, i.e. through immediate or purely qualitative experience. It can only be lived in the very specific moment of it is unfolding. Duration, therefore, cannot be applied to the world outside the self. The individual cannot perceive it; he/she can only experience it. To explain the concept of duration further, Bergson uses the image of a "melody." Just as in inner experience, each moment is radically discontinuous from the next, while giving the impression of flowing out of one and into another. A melody consists of different notes that succeed each other, while we perceive them as melting one into the other.

Nevertheless, Bergson does not see all existence as a continual free-flowing flux in which no states are ever 
permanent. Bergson makes a distinction between the inner and the outer realms of being, metaphysics and science, duration and time. Although for Bergson real living occurs in the indivisible realm of duration. In Matter and Memory, Bergson distinguishes between two types of memory: voluntary memory or habit memory, which involves the body and occurs through movements, and involuntary memory or pure recollection, which involves images and occurs through representations.

Voluntary memory is tied to the body. Things that have been learned by dint of practice and repetition are stored into this type of memory and can be easily recalled by the brain or the will for practical purposes. Involuntary memory, however, does not have a utilitarian function like voluntary memory. It simply records all the perceptions of past experience by the mere necessity of its own nature. It is the spontaneous surging up of lived moments from the past. Bergson prefers involuntary memory most, because it is immediately perfect from the outset, time can add nothing to its image without disfiguring it. Both types of memory are essential for a full realization of the spiritual life. They both integrate themselves in one another, creating a dynamic process of body and mind, present and past.

One of the other aims of Bergson was to include the element of creativity in evolution. According to him, the future could not be planned beforehand, as time itself unraveled unforeseen possibilities.

Bergson suggests that the world of living is governed by a certain life force, a creative energy called élan vital. The élan vital is a vital impetus, an image for the process of time as duration. It is the impulse common to all life that pushes us along, assuring continuity. It is also a source of creativity and difference as one cannot possibly know or predict the direction in which it guides us. The concept of élan vital thus accounts for evolutionary change, but in a less mechanical and livelier manner than other evolutionary theories.

Just as all living organisms are subject to the push of the élan vital which is at the origin of evolutionary change, so each organism also has its own élan vital which accounts for its individual evolution and explains the creative impulse of mankind. Through the force that is élan, vital the individual reaches a degree of higher complexity, a better understanding of the world around him/her and a heightened state of creativity. One of the other important concepts for Bergson was the theory of intuition, which is a kind of experience or empathy that leads us to understand the world of "Living" (inner life). Intuition involves identification with the thing itself, experiencing it from within. It is a kind of intellectual sympathy by which one places oneself within an object in order to coincide with what is unique in it. By approaching the object from inside, by entering into it as it were, we acquire what Bergson calls "absolute knowledge." In this case intellect cannot be forgotten. Without intellect, intuition would not be easily discerned. Intellect and intuition complete each other, and together they permit a fuller understanding of objects external to the individual, as well as of the inner world.
Mary Ann Gillies argues that:

For when we turn our gaze inward, we intuitively enter into an understanding with ourselves [sic] and then employ our intelligence to explain what intuition has revealed. Intuition becomes the means by which we may apprehend the essence, the organic wholeness, of other organisms and ourselves. (107)

Élan vital and intuition in tandem create an alternative approach to understanding the nature of life. While the former accounts for the way life evolves, the latter explains how we can experience objects outside ourselves. In this paper it was mentioned how the new inventions in the modern era affected the lives of people. These new inventions made people feel the differences between public time and private time heavily, because they felt, their living in two parallel worlds. At the same time with the changes in technology, philosophical ideas were also changed and reinterpreted. In the realm of the philosophy of time Bergson divided experienced time from physical time.

He believed that experienced time or duration can only be lived in specific moments of it's unfolding and only the individual can experience it. These ideas had a great impact on writers such as Mansfield and helped her make use of these theories in her stories. Bergson's philosophy generated a broad and varied cultural response, ranging from passionate support to frantic condemnation. His combination of science and metaphysics, his emphasis on intuition as opposed to intellect, and his preference for instability over stability excited many as the world was rapidly changing. Bergson's influence extended far beyond the French context to the rest of Europe, and even to the United States of America, transforming him into some sort of cult figure, worshipped by some, despised by others.

Bergson thus made a radical distinction between time and space, time being essentially heterogeneous and space homogeneous. Bergson writes, "What we must say is that we have to do with two different kinds of reality, the one heterogeneous, that of sensible qualities, the other homogeneous namely space" (1957: 97). Because time and space belong to two radically different worlds, one cannot transpose the laws from one to the other. To consider time in terms of space (i.e. as a homogeneous milieu) would imply simultaneity and to this extent refuse duration as the flow of time. It is difficult to understand this idea; therefore Bergson gives us the distinction between quantity and quality on the one hand, and numerous images such as the one of counting sheep on the other. When we want to count a flock of sheep, we consider the sheep to be the same. Therefore, quantitative multiplicity is homogenous; we make abstraction of the differences between the individual sheep. But despite their homogeneity, we can still count the sheep. This is because each sheep is spatially separated from or juxtaposed to the others; in other words, each occupies a specific location in space. Bergson's analysis of counting concludes that involuntarily, we always count in space, since counting requires juxtaposition, juxtaposition implies simultaneity, and simultaneity presupposes space. 
Bergson suggests that if we relocate time into space, we will lose contact with our own experience of time as flux and sensation as an inner experience. In his essay he suggests, "By introducing space into our perception of duration, it corrupts at its very source our feeling of outer and inner change, of movement, and of freedom" (74).

This brings up the question whether time as duration can be sufficiently represented by space. Bergson's answer is yes for the time that is already passed, but no, if one is speaking of the time that passes. Since action occurs in the time that is passing and not the time that is already passed, freedom is automatically associated with the domain of time passing or duration. As Bergson asserts: "All the difficulties of the problem, and the problem itself arise from the desire to endow duration with the same attributes as extensity to interpret a succession by simultaneity and to express the idea of freedom in a language into which it is obviously untranslatable" (221).

Bergson's other objective was to redefine the relation between science and metaphysics or intellect and intuition. As Mary Ann Gillies puts it:

He wanted to find a way of wedding the two and thereby allowing philosophy, and other intellectual endeavors, to mirror what the ordinary individual's common sense said: that the world consists of physical and spiritual aspects that necessarily work in concert to define human beings and their existence. (100)

In Bergson's theory the world of the spirit, cannot be explained by the laws of science. The movement that occurs in this world is in one direction only, quality cannot be reduced to quantity and states of consciousness cannot be separated, identified, named or counted. Life processes, according to Bergson, can only be known through the metaphysical method of intuition. The élan vital, a vital life force, causes a non-deterministic, spontaneous movement that cannot be predicted or measured in physical time. By Matter, Bergson means inert matter, that which is studied by the natural sciences. It is essentially static and if there is movement, the movement is continuous, reversible and predictable and the principles of mechanism and determinism prevail in the world of Matter. Every movement is predetermined, has its necessary cause and consequence; there is no freedom. In order to obtain understanding of this type of reality we measure things and discuss them in terms of logic.

\section{Time in Mansfield's Selected Stories}

Mansfield is widely considered as one of the best short story writers of her period. She is one of the early writers that used the stream of consciousness technique in her stories. She used this technique to create stories based on the illumination of character rather than the development of plot. In the last three years of her life Mansfield wrote some of her most technically assured and sensitively executed works. Her stories were recognized as rejecting the plotted action of nineteenth century short fiction and the center of her stories are on the question of character and personal identity. In fact her stories often focus on moments of disruption and frequently open rather abruptly. In Mansfield's hands the short story became a common modernist genre, capturing the troubled spirit of the age, and displaying an early and effective use of modernist techniques such as the internal monologue, stream of consciousness and so on.

She believed that true art must be a revelation that communicates the initial emotion felt by the artist to the reader. Her style is characterized by indirection where the characters thoughts are shown by suggestion and symbolism. Mansfield's stories center on the question of character and personal identity by using complex and uncertain view of personality, an emphasis on impersonal identity, determined by different social forces. Mansfield as a modernist writer enjoys experimenting with different stylistic methods of showing consciousness. Most of her stories focus on the conflicts and frustration of woman's life in a new liberated age. She frequently criticizes male oppression and female suffering. Joetze describes her lyrical writing as characterized by the relationship between parents and children, wives and husbands as well as siblings and among children. She impressively manages to narrate the psyches of uneducated working woman and young children to businessman and domineering matriarchs (13).

One of the most important issues for Mansfield in her stories is the notion of time. She usually tends to show time in her stories by her characters inner times and experiences. If there is any time in her stories there are many shifts in them, plunging from one characters mind to the other. It seems that she was influences by Bergson's concept of time in writing her stories. While working as an editor for John Middleton Murray in his journal called the Rhythm she was introduced to Bergson's theories for the first time. The way she shows her characters inner time in her stories, there duration and intuition seems close to Bergson's theory of duration which the researcher will explain in the following sections.

\subsection{Millie}

From Bergsonian point of view the whole story is about waiting, changing, remembering, and about checking the time. Form the very beginning in the first paragraphs of the story we can see the contrast between specialized time and duration. The difference between the two ways of thinking is showed in how they are expressed. As far as specialized time is concerned, there is no movement no change no existence of life in Millie's house where she is standing watching their departure. But this existence and change could be seen in the movement of Sid and his friend far away. As Bergson has mentioned in two different places there are different kind of times experienced, and this could be seen in this part of the story. Far away action and change and existence could be seen but not in Millie's house, there is no life, no noise and no movement. The part that Sid and his friend are riding the horses there is action but in Millie's house since there is no action and she is not doing anything there is no action. The 
specialized time is showed from the beginning by statements such as "half past two in the afternoon," in her thoughts Millie also says to herself that her husband won't be back until "half past ten." First of all this shows the specialized time and secondly it shows that she has been lonely and isolated so much that she cares about time very much and specialized time and life pass so long for her. To make it short as far as specialized time is concerned, nothing happens in the three opening paragraphs. The writer has used the long sentences in order to show duration. The long sentences give the reader an opportunity to experience what Millie experiences and feels and to observe how she changes. The reader sees everything that Millie sees and while she takes time observing her husband the reader takes time in reading long sentences without reaching the conclusion that nothing is happening. At the end of the third paragraph Millie starts moving mentally and physically in a more obvious way. The paragraph that she is describing the painting in her mind is made of two long sentences that suggest the continuance and heterogeneity of duration.

During the time that Millie is staring at the color print on the opposite wall, the reader can follow her line of sight and notice what she notices about the color print. In this way the writer keeps adding adjectives as if to show the heterogeneous of duration. Millie is a story about the narrators' memories too. In the next paragraph Millie starts feeling depressed and she does not know why herself. Although she does not realize it, isolation and loneliness for many years has made her mentally ill, and she is kind of living in the past with her memories.

She stares at her wedding picture and while she is involved in her memories, in the flow of time she suddenly realizes that she is alone and she has had no one to talk to in these years. After that she perceives that they have not had any children, and she tells herself that she has never felt there absence. This reminds us of what Bergson has said, perception occurs in the flow of time and it also involves ones memory. Millie is lying to herself, that she has never missed having children, because in the rest of the story we see how it has affected her all these years. When she sees the boy lying there so lonely, she suddenly feels this lack in her life "A strange dreadful feeling gripped Millie Evans' bosom - some seed that had never flourished there, unfolded and struck deep roots and burst into painful leaf" (Mansfield 485).

One of the important Bergsonian concepts in this story is the act of waiting. Millie has to wait until half past ten until her husband returns and it is only half past two. The time that she has to wait for her husband is unpredicted. What is important is that by representing the unpredictability of waiting time, Mansfield joins together continuity and heterogeneity in a way that they are combined with each other exactly as the way they are in duration. The following sentences are a good example for this:

And then she sat quiet, thinking of nothing at all, her red swollen hands rolled in her apron, her feet stuck out in front of her, her little head with the thick screw of dark hair drooped on her chest. Tick-tick went the kitchen clock, the ashes clinked in the grate, and the venetian blind knocked against the kitchen window. (Mansfield 483)

In the following sentences a sudden change occurs, Millie starts to tremble and gets afraid:

Quite suddenly Millie felt frightened. A queer trembling started inside her - in her stomach - and then spread all over to her knees and hands. "There's somebody about." She tiptoed to the door and peered into the kitchen. Nobody there; the verandah doors were closed, the blinds were down, and in the dusky light the white face of the clock shone, and the furniture seemed to bulge and breathe ... and listen, too. The clock - the ashes - and the venetian - and then againsomething else, like steps in the back yard. "Go an' see what it is, Millie Evans. (Mansfield 483)

As if she is listening to an unknown melody, Millie is suddenly surprised by a change. This shows the heterogeneous notion of time, that although duration is continued and no part is separated from the other part, change occurs in it continually.

The concept of waiting can be seen in another part of the story, where it is night and Millie and her husband are preparing to sleep. In this part Millie is waiting nervously to see when the boy will escape. She is anticipating every sound and movement to see if it is him.

The house dropped quiet. She lay and listened. Little pulses tapped in her body, listening, too. It was hot. She was frightened to move because of Sid. 'E must get off' 'E must. I don' care any think about justice an' all the rot they've bin spoutin' to-night," she thought, savagely. "Ow are yer to know what any think's like till yer do know. It's all rot." She strained to the silence. He ought to be moving ... Before there was a sound from outside, Willie Cox's Gumboil got up and padded sharply across the kitchen floor and sniffed at the back door. Terror started up in Millie. "What's that dog doing? Uh! What a fool that young fellow is with a dog' anging about. Why don't 'e lie down an' sleep." The dog stopped, but she knew it was listening. (Mansfield 486)

After this part Millie is again surprised by a sudden change, which is the barking of the dog. It is as if she has waited too long for a change, or she is not allowed to wait as long as she wishes. The time that she is waiting, although it may seem short starts to get very long for Millie. Duration that is within each individual's consciousness is made of qualitative sensations or experiences, not numerical aspects. In an individual, in the continuous flow of duration, one minute could be felt as if it were longer than that because that particular minute has a kind of importance in one's duration, as it is in the case of Millie. In the sentences above the notion of specialized time can be found in statements such as, "The house dropped quiet," "She lay and listened," "She was frightened to move because of Sid," and "She strained to the silence." All of these sentences deny movements and the existence of life. As far as space (specialized time) is concerned, it can be said that nothing happens in this part of the story.

According to Bergsonian notion of time, it can be said that 
these statements are based on time which has already flown, but just like a melody they are melted into the next moments and bring to life the next minutes, which are unpredicted and although they are different they are continued in each other.

In the same paragraph the use of present participles such as "Millie lay on her back, her eyes wide open, listening," "Little pulses tapped in her body, listening, too," "He ought to be moving" and "The dog stopped, but she knew it was listening" are designed in a way to let the reader experience duration. These statements give the scene a sense of presence and continuity and they also make the reader conscious of the time which is passing right now.

To make it short, Mansfield shows two phases of duration, continuity (indivisibility) and heterogeneity (unpredictability), in Millie by showing a woman character who is waiting for change, not only through the story, but in fact she has been waiting for change all her life.

\subsection{New Dresses}

Helen feels alienated from her family because no one understands her, except her grandmother. In regard to this issue Clare Hanson says:

Helens inability to adjust to her role and satisfy her parents is due primarily to a faulty relationship with her mother. Mrs. Carsfield rejects in Helen those aspects of herself which she finds it inconvenient to remember_ she complains of the irritating shrug which Helen has picked up from her, and the stutter which she herself had at Helens age. (208)

It seems that Anne (the mother) is trying to recover from her childhood defects by persuading her girls to do things she did not do and to keep them decent by sewing them expensive dresses. Instead of being considerate of her daughter's feelings the only important thing for her is to make them look decent. Henry the father is a very selfish arrogant person and the only important thing for him in the world is his son Boy. He does not treat his children in a kind way and he even goes to the point of insulting and whipping them. This has put Helen in a kind of prison and she wishes to get free form this prison. The main reason that she is jealous of her baby brother is that he is given the freedom she and her sister are denied. Their house that is perfectly controlled by rules, promises its occupants security but not freedom. It can be argued that the fact that Helen is a child may suggest some future changes in her and her life, she may be freed in the future, just as Hanson suggests "In New Dresses the possibility of freedom is presented, but in terms of an unconvincing fantasy ending" (209). However in Bergsonian terms it is impossible to predict how she will change in advance. From the very beginning of the story we can see that the characters are obsessed with linear time and it has completely affected their life. An example could be seen in the part that the grandmother is trying to defend Helen, she wants to tell Anne that she and her husband must be better to Helen, but the ticking of the clock distracts her and she forgets what she was supposed to say:

The old woman put down her work on the table. A little silence fell, and through the silence the loud ticking of the dining-room clock. She wanted to speak her mind to Anne once and for all about the way she and Henry were treating Helen, ruining the child, but the ticking noise distracted her. She could not think of the words and sat there stupidly, her brain going tick, tick, to the dining-room clock. "How loudly that clock ticks," was all she said. (Mansfield 454)

We can easily see the notion of specialized time and its effect on the old woman in this paragraph. Linear time has dominated her life in such a way that even the power of thinking has been got from her. The tick, tick of the clock distracts her very much. The repetition of the words silent, tick, tick and dining room clock show the notion of the power of specialized time over duration and the old woman. In other words they have distracted her from her intuition and duration. It is as if there is no existence and sound there in regard to specialized time. The statement "She could not think of the words and sat there stupidly", means that she could not say anything or did not want to say anything. If we want to look at it from Bergson's point of view, it is a time which has already flown. We can say that these words are either uttered from a determinist point of view, which wants to indicate that it is pre-destined that the old woman cannot say what she wanted to at this point, or we can say that it is on the grounds of the supporters of freedom, which means there will be two possibilities: that the old woman says what she wants to say or she doesn't. At this point she chooses not to say. Bergson argues that both of these attitudes fail in capturing duration since they see the action from the view point of time in which the action has already been finished in. He means to say that they focus on the result, not the process.

It can be seen in the story that the characters especially the mother and father refer to the next day which is Sunday very much. They go on and on talking about Sunday and going to church, and this shows how much this day is important for them. They know what they will do on this day (going to church) and mostly what will happen. Also other expressions such as "they're hell upon earth every month, these bills," "she returned to the garden in the every-day dress;" show the predictable and static life style of the characters. These words are not based on Bergsonian duration, because our duration is irreversible. We cannot live a single moment over again, because we should begin removing the memory of all that had followed. The characters live like beings whose consciousness is paralyzed, "For a consciousness being, to exist is to change, to change is to mature, to mature is to go on creating oneself endlessly" (Creative Evolution 8).

To make it short the characters in the story suffer from a life that is always the same. The same routine, the same day, weekend and month repeated over and over again. The same thing happens when the members are with each other. The mother and father always scold Helen. Anne is bored because her mother always speaks of the same thing with her, her husband always complains to her. There is no change in their life and they have become the slave of linear time in search of freedom and change. This can be the opposite of one of her other stories which is called "The Little Girl," although the heroine is also treated badly by her father in this story, in 
the end a change occurs and a reconciliation between the father and daughter is attained.

\section{Time Experience According to Status and Age in Mansfield's Stories}

One of the important aspects of Mansfield's writing is that, she includes the notion of space and its social implications under the question of time in her stories. This includes the perception of time, and the existential conditions related to the passage of time, such as age, or the point in time in the characters life. Mansfield's characters often hold different outlooks on the passage of time and meaning of life, according to their age and there life status. Mansfield favors certain ages such as childhood, adolescence and old age. Her adult characters mostly tend to be dull or unimaginative. They are otherwise too confused or entangled with themselves to be able to appreciate any option they may have. This applies to both men and woman. Being in a certain age (as well as gender, marital status, class) affects our perception of time.

\subsection{Old Age in Mansfield's Stories}

The elderly characters of Mansfield's stories are mostly lonely and isolated, although they have the wisdom of age and experience. It seems that there is a kind of unsuitability between them and the social and existential conditions. Life of Ma Parker is one of Mansfield's stories that the protagonist is an old woman. In this story for the first time Ma Parker realizes that although she has had a hard life until now and she has bore it, she cannot bear it anymore. She realizes that she is tired of her life and wants to cry for the first time in her life. The time span is only a few hours on Tuesday. The old woman Ma Parker cleans the flat of a literary gentleman every Tuesday. In the story it is Tuesday and she has come to clean his flat like always. After knocking on his door the literary gentleman opens the door and asks about her grandson. She answers that they have buried him the day before. The man answers that he is sorry while eating his breakfast and holding a newspaper in his other hand. He feels awkward because he thinks he should say something else before going to the sitting room, so he only says that he hopes the funeral was a success. It seems that Ma Parker does not hear him at all because she does not answer him and goes to the kitchen to get ready for cleaning. Ma Parker starts cleaning the house, and while doing this in her consciousness she is taken to a new world with her grandson, fantasizing about him, and remembering moments with him. She remembers that he used to sit on her lap and ask for money, while kissing her and pressing closer to her.

The story then describes the state of the kitchen as a gigantic dustbin. We are informed that the literary gentleman does not do anything himself. He does not even clean forks. If he needs one he just wipes a dirty one with a towel and uses it. He believes that you should dirty everything you have and get a housekeeper once a week to clean it up. While Ma
Parker sweeps the floor she tells herself that she has had a very hard life. The story goes into her consciousness into the past again and she remembers that she left Stratford when she was sixteen and came to London to work as a kitchen maid. She remembers that it was a very bad place and she was never allowed to go out. The cook has also been a very cruel woman and never gave her the letters that they wrote to her from home. After that she went to work as help to doctor and stayed there for two years. It was there that she met her husband who was a baker and married him. They had thirteen children and seven of them died while they were young. While the other six children had been young her husband had become ill and died. She remembers that it had been terrible raising those six young children all by herself and when they went to school her husband's sister came to help her but she fell down the stairs and hurt her spine. Ma Parker was persuaded to take care of her like a baby for five years. She recalls that her young girl Maudie became a prostitute and made her sister Alice become one too. Her two sons immigrated to another place, her other boy Jim went to India with the army and her youngest daughter Ethel married a waiter who died soon after their boy Lennie was born.

She finishes most of the cleaning and thinks about her grandson again. She remembers that he had never been a strong child from the start. She and her daughter had done all they could to make him gain some weight but it had been of no use and he had always been slim. In the next part the literary gentleman informs her that he is going out for a walk and has put her money in a tray. He then tells her that if she ever threw away something she should tell him. Ma Parker then goes to clean the bedroom and while making the bed she wonders why her grandson suffered so much. Something in his chest seemed to boil and made him cough all the time, in a way that he could not bread at all. Ma Parker feels that can't think about it anymore. She has born too much hardship in her life, and she has always kept it to herself and never cried. Even her children have never seen her cry because she has always been proud. She feels that the only thing she got from life was Lennie and she has lost him too. She has nothing left in life, and for the first time she questions why all this should happen to her. It suddenly seems that she does not know what she is doing. She puts her dress on and gets out of the flat like a person in a dream. It seems as if she is feeling the horror of the tragedy that has happened to her for the first time, or she has just realized what she has lost and what has happened to her. She wants to go to somewhere, just to escape from all this misery. When she gets into the street she sees that the people are walking here and there. She knows that if she cries no one would care, but the thought of crying makes her feel relieved. She feels she wants to have a proper cry over everything in her life for the first time, from the very beginning where she worked in the kitchen until her grandson's death. But the problem is she can't find a proper place to cry. She decides to go home, but her daughter would get really frightened, seeing her mother crying for the first time. She can't cry in the street because the people will question her and it is wrong to go to the gentleman's flat 
because it is not good to cry in a stranger's house. If she sits on a step the police will question her. She gets irritated because she sees there is nowhere for her to even cry and be lonely for some time. While trying to look for a place it starts raining and Ma Parker is not able to find anywhere anymore. It seems that even nature is against her. The story describes Ma Parkers increasing loneliness, within her family and society. We can see the sense of overwhelming loneliness and isolation that is affecting the old woman. Throughout the story she goes on thinking about her beloved little grandson and remembering their memories together and even fantasizing about him. It can be said that although Ma Parker has a hard life, her grandson had been a great company and remedy for her, and had brought difference to her life, but he is now given over to sad memories and has made Ma Parker lost in the time of her past. It seems that Ma Parker is in two worlds in this story. On the one hand she is working and performing her duty, while on the other she is recollecting her past, and reflecting on life altogether. What Ma Parker is doing and what she is thinking belong to two separate spheres, the former belongs to the realm of the present and the latter is in the realm of the past. Clare Drewery (2011) believes:

$\mathrm{Ma}$ is caught in the luminal predicament of being between two worlds. The world of the social order is conveyed through class distinctions that pervade Ma's discourse. Even her reflections on mourning are conveyed through the language of her household chores. (40)

Despite the fact that her grandson's death is a tragic thing to recall, she has to suppress her feeling and face the day to day work. The fact that Ma Parker is an old woman puts her in more danger to be drowned in the past. The present existence of Ma Parker actually includes her whole life or whole memory of the past. This could be an example of what Bergson believes about the past and present. He believes that the past and present are united in the sense that human consciousness moves freely between them (Matter and Memory, 211-12). We can look upon Ma Parkers duration (her inner time) with regard to her social position too. As a person in a low social position who has to work to earn money, Ma Parker is not that free to have a time to herself, is not that free to pour out her grief. Drewery claims:

In fact "her time is governed by a need to earn a living, and while doing this she cannot vocalize her grief. Her important duty in life is to earn a living, and as her time is paid for, she cannot own her life or even her grief."(40)

That is why she cannot find the time and place to cry and the story ends so sorrowfully. It seems that the society, her own children and even nature are against her, because none of them will allow her to express her misery through tears. In most of her stories about the time of the old, Mansfield shows a delicate and simple account of their perceptions and conditions. These conditions are often expressed through symbols and metaphors, sympathetically emphasizing the difficult situation of this age.

\subsection{Adolescence in Mansfield's Stories}

Mansfield describes adolescence as a relatively changeable, fairly innocent period, in her characters life. She shows the quality of indetermination and openness that is special to this age in her stories. It is an age in life that, people still have many options open to them. It is a time for trying out new things and new modes of being. Good example of her teen-age characters in Mansfield's stories are those of "The Garden Party" (1922)

The first story is "The Garden Party." The story is full of time interruptions and anachronism. Mansfield shows the Heterogeneity of the self, which is plunged into continues flow of time. He goes on jumping from one memory to another with no order. The events of his life that are buried in his unconscious come and go unpredicted, showing different psychic states every moment, such as his childhood memories, his memories from a different house and so on. As in Bergson's concept of duration, William experiences his inner life as complex, qualitative multiplicity. In Mansfield's stories there are circumstances which force her characters into the time of their past. These are the old people. Although they have a future, as well as action and linear time, this time is significantly reduced or coming to an end which forces them to think of their sorrowful or happy past more than any other time. They may also feel isolated and lonely in society. This story covers the time-span of one day of the life of the Sheridan family who are rich people. The story is told in the third person point of view, but it mostly takes place in Laura's consciousness, and duration. The position of the narrator is both inside and outside the character.

Laura the central figure of the story is in the age of adolescence, which is a time for changing and evolution. The insistent desire to experience new things during adolescence could be seen in the following expression from the story, "But still one must go everywhere, one must see everything" (Mansfield 204). This displays the curiosity of adolescence Laura and her brother Laurie, and their need to explore and investigate everything and new things. In the story Laura is confronted with death for the first time in her life. While this is something quite normal for the rest of the family, she considers them as "heartless." They accuse Laura of being extravagant and they believe that since the death happened in the lower classes it can be dealt with by sending a gift. For Laura it is a new, crushing experience casting a shadow on her day, making her question everything in her life. Laura is thrown from the linear daily routine of her life where there is no change and she is happily living in, into a new life were she has to accept death and the absurdity of life. Patrick D. Morrow (1993) says about this, "This encounter with death, after an afternoon abounding with life and all its pleasures provide Laura with her first lesson about the discrepancy between life's apparent rationality and its actual absurdities" (74).

Throughout the story we see that she has mixed feelings about social differences. Her internal struggle is about identity, whether to imitate environmental influences or react in a way that is unique to her personality and deep in her mind she knows is right. She is in a kind of duality with herself regarding this issue and she does not know whether 
she should accept these differences like her family or stay against them. Although she does not accept these differences she has accepted her role in society as a rich person and acts as one. During the story we see that she changes according to circumstances. But at the end of the story when she goes to the dead man's house it has a very serious impact on her, it can be said that crossing the physical space between the partying family in the garden and the desolation of death and poverty across the lane is a minimal but significant journey for Laura.

In fact throughout the story Laura goes on experiencing new things. It is true that while experiencing new things she goes on changing or maturing, but the past Laura remains within her as an unseparating part. This shows the continuity of Laura's duration as Bergson believes that the "evolution" of a living being, implies a "continual" recording of duration, a "persistence" of the past in the present (Creative Evolution 20). When Laura goes to see the dead man she walks through a "gloomy passage," which symbolizes her journey from childhood to adulthood. When she meets the dead man's wife, she realizes the class distinctions; the dead man's wife is pictured as a not very beautiful person. But the dead man is pictured as someone beautiful and sleeping peacefully. In other words "Laura learns that while poverty is hindrance to beauty death makes boundaries disappear" (Alonso 86). The end of the story shows that a shift has taken place in her consciousness. On the way home she is unable to find the words to tell her brother what she feels, because she has ventured to a wild zone of her own that she cannot explain. The fact that Laura is in the age of adolescence gives her the time and chance to change her views and mature, and be someone completely different from her family. Just as Bergson believes that "for a consciousness being, to exist is to change, to change is to mature, to mature is to go on creating oneself endlessly" (Creative Evolution 8). At the end of the story although Laura's view changes about life and a new stage begins in her life, and she completely comes out of childhood, it is not mentioned what path she would choose, whether rebel against the social conditions of her society or accept them. So Laura may change or she may not change, however in Bergsonian terms it is impossible to predict how she will change in the future.

\subsection{Adulthood in Mansfield's Stories}

Adulthood is an almost tragic period in the lives of Mansfield's characters, a time that requires taking stock of used opportunities and considering the options left. This could be seen in one of her popular stories called Marriage a La Mode. It is a story about a couple who are having problems in their marriage.

The first two thirds of the story is written from William's point of view, Then it shifts to Isabel's in the remaining one third of the story. The reader is presented with the point of view of this couple, which however never has a chance to intermingle. Despite their position as husband and wife, William and Isabel scarcely have a chance to communicate and understand each other's view. The story ends on a pessimistic note that Isabel will continue to pursue her new ways, which means that she will continue to use her discourse. In "Marriage A La Mode" William the protagonist goes on remembering the good days he had with his wife in the past. This past obviously occupies a large part of his inner life, threatens to take over the present, disrupting his usual activities. In the story the time shifts constantly from present to past. We follow the duration of a man who considers his current life and remembers or rather is obsessed by his early marriage life. The story is full of time interruptions and anachronism. He feels that his marriage is in crisis because his wife has changed. He recalls that he was happy with his wife at first and they had a good life together, but after a while he understood his wife is not happy. Thorough William, Mansfield shows the Heterogeneity of the self, which is plunged into continues flow of time. He goes on jumping from one memory to another with no order. The events of his life that are buried in his unconscious come and go unpredicted, showing different psychic states every moment, such as his childhood memories, his memories from a different house and so on. As in Bergson's concept of duration, William experiences his inner life as complex, qualitative multiplicity.

One of Isabel's satisfactions is to save time, to fit in with the clock. We could see this from the part that William remembers how she chose toys for the children. She threw away their old toys and bought new French and Russian toys for them, "It's so important the new Isabel had explained," in a sentimental way of her new behavior "that they should like the right things from the very beginning. It saves so much time later on" (Mansfield 250).

We can see another example at the near end of the story when she is waiting for the post and feels that it is late like always or when she is saying goodbye to William and wants to end it and go back to the house as soon as possible. In this part she complains that the time they spent together was very short which shows she feels she has not made use of the time as much as she could. It seems that she is pursued by the clock all the time and fits in as many things as possible in the shortest possible time. The adult characters in Mansfield's stories experience time according to the social position that they hold and the class they have in society. Mrs. Sheridan, Laura's mother in "The Garden party" offers a good example of the rich people in Mansfield's stories. Mrs. Sheridan is an adult, rich character. She has complete dominance over her household and children. She could be considered as an image of female power. Unlike her daughter Laura, she has completely accepted the social differences. She does not feel any sympathy for anyone, except those who are related to her own household and class. For example, when informed that a worker has died she first thinks that he was one of the workers in their own garden but when assured that he was from somewhere else she feels relieved. The reason is that as an adult character, she has become set in her ways, or on the other hand, her social position and circumstances hardly allow her any room for change.

Another example could be Isabel's rich artist friends in 
Marriage A La Mode. Her friends do not worry about linear time at all. They seem to be in search of ways to just pass the time and engage in activities such as bathing or sitting under the sun and speaking about strange things. For example one of her friends Moira tries to sleep in order to just pass the time. She has discovered that one of the best ways to pass the time is just shutting the eyes and sleeping. The reason for this could be that they are somehow trying to run from their consciousness and don't want to think about life and its difficulties. They do not want to believe that they are leading an aimless life with nothing to do. In Mansfield's stories there are circumstances which force her characters into the time of their past. These are the old people. Although they have a future, as well as action and linear time, this time is significantly reduced or coming to an end which forces them to think of their sorrowful or happy past more than any other time. They may also feel isolated and lonely in society. I will give a more explanation of the old people's time in the next part.

\section{Conclusion}

The researcher was proved how being in different conditions affects perceiving and experiencing time. Being in a certain age such as Laura totally affected her consciousness, also the incident that occurred for her had a great impact on her in such a way that she was somehow distracted in many parts of the rest of the story. In "Marriage a La Mode" William, regardless of the age that he is in, the condition that he is in affects his experience of time a lot. For example on his way home from London although the distance is far and he has always felt it before, this time because he is thinking of his marriage problem, he does not feel this distance anymore and is surprised that the time passed so quickly. This shows that his problems affected his time experience. These factors could also be seen in the two other stories that were analyzed. To make it short being rich or poor, happy or sad, old or young and finally being at ease or in disturb influences the perceiving of time in people. The characters of these stories live in the world of their own. They are either rooted in their memories, or they are in search of change. The notion of the linear time has affected some of her characters life and has even taken the power of thinking from them. In order to show the characters attitude towards time and the notion of time in Mansfield's stories, it was important to analyze these stories. The major issues that were questioned included the significance of time for Mansfield's characters, the way she dealt with time in her works and the way she was influenced by Bergson's philosophy. Eventually how her characters perceive time under certain conditions and age.

\section{References}

[1] Abrams, M. H. A Glossary of Literary Terms. New York: Pearson Longman, 2005.
[2] Alonso, Pilar R. "The Role of Intersentential Connectives in Complex Narrative Discourse: Katherine Mansfield's 'The Garden Party'." Miscelanea: A Journal of English and American Studies 17. 1996: 17-38.

[3] Bergson, Henry. Creative Evolution. Trans. Arthur Mitchell. London: Macmillan, 1911.

[4] Matter and Memory. Trans. Nancy Margaret Paul, and W. Scott Palmer. London: Allen and Unwin, 1911.

[5] Time and Freewill: An Essay on the Immediate Data of Consciousness. Arthur's Preface. London: Riverside press, [1957].

[6] Bunyan, John. The Pilgrim's Progress. New York: Oxford University Press, 1998.

[7] Defoe, Daniel. Robinson Crusoe. New York: Dover Publications, 1998.

[8] Drewery, Claire. Modernist Short Fiction by Woman: The liminal in Katherine Mansfield, Dorothy Richardson, May Sinclaire and Virginia Woolf. Burlington: Ashgate Publishing Company, 2011.

[9] Gillies, Mary Ann. "Bergsonism: 'Time out of Mind'." $A$ Concise Companion to Modernism. Ed. Davidn Bradshaw. Malden: Blackwell, 2003. 95-115.

[10] Henri Bergson and British Modernism. Montréal: McGillQueen's University Press, 1996.

[11] Goethe, Johann Wolfgang Von. Faust. Trans. Bayard Taylor. New York: Echo Library, 2006.

[12] Hanson, Clare. "The Aesthetic of Katherine Mansfield." Diss. University of Reading, 1980.

[13] Joetze, Steffi. Literary Modernism: Katherine Mansfield and the Short Story. Norderstedt: Druck Und Bindung, 2010.

[14] Joyce, James. A Portrait of the Artist as a Young Man. London: Penguin Books, 2000.

[15] Kern, Stephen. The Culture of Time and Space: 1889-1918. Cambridge: Harvard UP, 2003.

[16] Mansfield, Katherine. Collected stories of Katherine Mansfield. Hertfordshire: Wordsworth editions limited, 2006.

[17] Mendilow, A. A. Time and the novel. London: Faber and Faber, 1975.

[18] Meyerhoff, Hans. Time in Literature. Engleweed Cliffs: University of California Press.

[19] Morrow, Patrick D. Katherine Mansfield's Fiction. n. p. Bowling Green State University Popular Press, 1993.

[20] Nakano, Eiko. "One or Many: Bergsonian Readings of Katherine Mansfield's Modernism." Diss. University of Sterling, 2005.

[21] New, William H. Reading Mansfield and Metaphors of Form. Quebec: McGill-Queen's UP, 1999.

[22] Poulet, Georges. Studies in Human Time. London: The John Hopkins Press, 1956.

[23] Smith, Angela. "As Fastidious as though I wrote with acid': Katherine Mansfield, J. D. Fergusson and the Rhythm Group in Paris." Journal of the Katherine Mansfield Society 3. 2011: 4-20. 
[24] Stevenson, Randall. Modernist Fiction: an Introduction. Hemel Hemstead: Harvester.

[25] Greenwich Meanings: Clocks and Things in Modernist and Postmodernist Fiction." The Yearbook of English Studies 30. 2000: 124-136.
[26] Wild, John. The Challenge of Existensialism. California: Indiana UP, 1966.

[27] Zerzan, John. Time and its Discontents. Berkley: University of California Press, 1962. 